\title{
RULE OF LAW AND NIGERIA'S ANTI-GRAFT WAR: THE EDUCATIONAL IMPERATIVE AND ELITE THEORY INTERROGATION
}

\author{
Hannatu Kungaba ${ }^{1^{\star}}$, Jide Ibietan ${ }^{2}$, Ugochukwu Abasilim ${ }^{3}$ \\ ${ }^{1} \mathrm{Ms}$, Department of Political Science \& International Relations, \\ Covenant University, NIGERIA, hannatu.kungabapgs@stu.cu.edu.ng \\ ${ }^{2}$ Dr, Department of Political Science \& International Relations, \\ Covenant University, NIGERIA, olajide.ibietan@covenantuniversity.edu.ng; \\ ${ }^{3} \mathrm{Dr}$, Department of Political Science \& International Relations, \\ Covenant University, NIGERIA, ugochukwu.abasilim@covenantuniversity.edu.ng \\ ${ }^{*}$ Corresponding Author
}

\begin{abstract}
The paper examines the efficacy of rule of law as an instrument for prosecuting the anti-graft war in Nigeria. Predicated on literature, it is observable that attempts at reducing the incidence of corruption (through various legislations, policies and institutions) in Nigeria's public life predates independence. However, these have not yielded the desired results. Using elite theory as framework of analyses backed by secondary data and textual analyses, the paper identified that the unimpressive impact or lack of vigour of the rule of law on the anti-graft war in Nigeria is traceable to (governing and bureaucratic) elite complicity and weak institutions of governance. Attitudinal re-orientation via educational imperatives on the part of political and bureaucratic elites anchored on rejuvenated public institutions would attenuate these dysfunctions. Other recommendations of the paper are capable of addressing the issues identified.
\end{abstract}

Keywords: Anti-Graft, Education, Law, Military, Democracy, Nigeria

\section{INTRODUCTION}

Nigeria first became a republic in 1963 and transitioned from a parliamentary system of government to military government and this brought its first republic to an abrupt end. Ikejiani-Clark in (Yunusa \& Abuh, 2016) maintains that the history of graft is traceable to the colonial era where corruption was prevalent in politics, public bureaucracy and private sector. Clerks were paid bribe to by-pass regular processes and have their files atop others on the Administrator's desk. Corruption in the colonial era was also evident in the misuse of government property as the citizens were oblivious of it. Another evidence of corruption was the appointment of political elites into positions of political power without the means to finance their political careers. While this may be true, Ibietan (2013) argues that colonialism ended over sixty years ago and some traditional political-economists still blame Africa's misfortunes on colonialism.

The Nigerian military's justification for intervention in government was to bring an end to the corruption of the First Republic (1960 to 1966) and restore order. It is no debate that military rule truncates the rule of law of a country and the rights of its citizens, this is because military government comes into power by toppling existing legal order and replacing it with decrees. There is substantial evidence that the Nigerian military governments were characterised by absence of the rule of law (Nwogu in Onyegbula, 2017). The reemergence of civilian rule brought hopes, but Nigeria's anti-graft war is still in deficit as the country was 
ranked $149^{\text {th }}$ most corrupt country in the world by the Corrupt Perception Index (Transparency International, 2020). The level of apathy, indifference, doubt in public discourse and about political leaders, the declining confidence in government as well as the rule of law in Nigeria show that democracy, good governance and development have not taken firm footing (Ayatse, Onaga \& Ogoh, 2013). The rule of law should be guaranteed in a democratic system of government with defining emblems like separation of powers, independence of judiciary, checks and balances and the protection of human rights and freedoms. The rule of law is unmistakably spelt out in the 1999 Constitution of the Federal Republic of Nigeria, but disrespect for the rule of law by those who should uphold its sanctity is quite disturbing and curious. Over the years, there have been various anti-graft agencies and policies put in place by successive governments, these have not impacted largely on the graft war, due to the attitudinal lapses that calls for re-orientation and educational imperatives.

\section{LITERATURE REVIEW}

The concepts of the rule of law and graft are explained in this section.

\subsection{The Concept of Rule of Law}

The rule of law entails justice according to documented procedures, not based on the whims and caprices of any individual (Iwuoha, 2019). It is that feature of the law which presumes a political system where life is structured according to the constitution that guarantees a good degree of impartiality in dispensing justice (Onwanibe in Adegbami \& Uche, 2016). It is the predominance of legal documents as opposed to the influence of arbitrary power and excludes the existence of prerogatives and wide discretionary powers of government (Dicey, 2013:120). The principles prescribed for the complete realisation of the rule of law by Dicey are that:

legal duties and liability to punishment of all citizens is determined by the ordinary (regular) law and not by any arbitrary official fiat, government decree or wide discretionary powers; disputes between citizens and government officials are to be determined by ordinary courts applying ordinary law; fundamental rights and freedoms are rooted in natural law and are not dependent on any abstract constitutional concept, declaration or guaranty

The rule of law prescribes that the actions of government and those governed must always be justified legally, this implies that citizens and government officials must be bound by the constitution and those found wanting should face the consequences. The rule of law is described by Amali (2017) as a distinct concept whose meaning and structure varies in different settings. For example, while the military claimed to be observing and obeying the rule of law, it was ruling by force, this in itself contradicts constitutionalism. The rule of law is necessary for upholding justice in a society. Haruna \& Yusuf (2017) corroborate this point based on the supremacy of law over the whims and caprices of the state or its leading personnel.

The rule of law as enshrined in the 1999 Nigerian Constitution encapsulates the following: Every citizen is subject to the ordinary laws of the state and this is buttressed in Section 1 (1) of the 1999 Constitution which states that the constitution is supreme and its provisions binding on all citizens and authority. The second principle is equality before the law, all citizens are equal before the law and subject to its courts. Sections 17 (2a) specifies the equality of rights, obligations and opportunities in the law. The third principle is the principle of human rights and basic freedom. The inalienable rights of every citizen is guaranteed under the rule of law. Chapter Four outlines all the rights that citizens are entitled to as human beings. Some of these are: right to life, right to dignity, right to fair hearing, right to freedom of expression and many more. The rule of law prohibits the arbitrary use of power by the government. It also means that governance must be done in accordance with due process.

\subsection{The Concept of Graft}

Graft is also known as Corruption, and the two are used interchangeably. Graft is pervasive bribery and embezzlement by state officials which usually signals that the integrity of governing institutions have broken down (Darden, 2000). Graft is analysed in the work of Heidenheimer (1970) as categorised thus:

1. The market-centred school which studies the behaviour from the viewpoint of the supply-demand model. Here a civil-servant is likened to a businessperson who uses his office as an income-maximising instrument.

2. The public office approach which is the theory of public office and the rules/ethics that serve as guidelines for public office holders. In this approach, corruption is defined as the subservience of public interest to personal agenda which involves the infringement of the rules of conduct of duty and welfare, accompanied by secrecy, betrayal, deception and disregard for the consequences suffered by the public. 
3. The public interest approach assesses an act based on its compatibility with public interest.

Rotimi, Obasaju, Lawal \& Iseolorunkanmi (2013) posit that corruption includes bribery, fraud, smuggling, money laundering, illegal payments, drug trafficking, falsification of documents and records, window dressing, false declaration, evasion, underpayment, deceit, forgery, concealment, aiding and abetting of any kind to the detriment of another person, community, society, or nation. Corruption connotes the abuse of public office through the instrumentality of private agents who actively offer bribes to circumvent public policies and processes for personal advantage and profit. Public office can also be abused for personal benefit through patronage and nepotism, for example, theft of state assets or diversion of state revenue.

The Corrupt Practices and Other Related Offenses Act, S. 8. (2000) in Chapter Two defines corruption as:

...bribery, fraud and other related offences. Bribery is also used synonymously with gratification, which is defined in the Act, Section 8 to mean money, donation, gift, loan, fee, reward, valuable security, property or interest in property whether movable or immovable or any other similar advantage, given or promised to any person with intent to influence such a person in the performance or nonperformance of his duties.

Implied in these definitions are those: corruption is bad and an indication of deformed values, another is that it is an abuse of power and the trust of those who elected/appointed such public office holders into office. Corruption is not limited to only public officers, but also to the privileged, elite and ordinary citizens. Corruption is a global issue but the intensity, refinement and form vary from country to country.

\section{THEORETICAL FRAMEWORK: ELITE THEORY}

The theoretical framework considered applicable to this study is the Elite theory. The Elite theory was developed by Vilfredo Pareto and Gaetano Mosca. They argue that elitism is inevitable and a classless society is non-existent. Mosca asserts that the elite use democracy to secure legitimacy for their rule. This way, power is consensually handed over to them. Recent application/references to this theory were made by Onah \& Ibietan (2010) and Ibietan \& Ajayi (2015) with the averment that the study of politics is one of influence and how influential people control national resources. The elite theory believes that power is concentrated in the hands of only a few number of people in the society. It divides members of the society in two, the rulers and the ruled. The theory places emphasis on inequality. Also, the elites are typically more informed as they have more access to education and power (Pokharel, 2019). The main driving force for the influence of elites in politics is the protection of their interests and their status-quo, the theory argues that all men love power, hence, those in power do not want to relinquish it, but hold on to it through any means.

Corruption is seen as a means for elites to protect their personal and selfish interests and maintaining their positions in the society. Elitism also prevents the governing and bureaucratic elite from being duly prosecuted for their crimes, the activities of political elites continue to cripple the anti-graft war and negate the provisions of the rule of law. Ibietan \& Ajayi (2015) attribute the lack of accountability of the Nigerian elite to weak government institutions and the fallen status of Nigerian laws, these explain why institutions (Code of Conduct Bureau, Economic and Financial Crimes Commission, the Judiciary, Independent Corrupt Practices Commission) charged with the responsibility of maintaining moral rectitude in government, and integrity in public affairs have not been very effective.

\section{DISCUSSION}

\subsection{Anti-Graft Intervention (1966-1999)}

Various agencies and policies have been established to address the menace of corruption in Nigeria. Major Kaduna Nzeogwu in a speech after the first Nigerian military coup on $15^{\text {th }}$ January, 1966, assured Nigerians that one of the reasons for the coup was to bring an end to corruption, nepotism, mismanagement and tribalism. Despite the seemingly stringent edicts and rules, Nigeria has not fared any better. At the end of military rule in 1999, the country was already one of the most corrupt countries in the world (Transparency International, 1999).

The General Aguiyi Ironsi military government that replaced the toppled civilian administration instituted commissions of inquiry to investigate the activities of some government parastatals and to probe the widespread corruption that characterised the public sector. Reports from the Nigeria Railway Corporation, Nigerian Ports Authority, the defunct Electricity Corporation of Nigeria and Nigeria Airways revealed that a number of ministers formed companies and used their influence to secure contracts. Moreover, they were found guilty of misappropriation of funds as well as disregarding laid down procedures in the award of contracts by parastatals under their ministries (Aloko \& Abdullahi, 2018). The determination to redress these 
was short-lived as General Ironsi was ousted in a bloody coup and replaced with General Yakubu Gowon in July, 1966. The Yakubu Gowon regime witnessed unprecedented wealth from the oil boom, mismanagement, redirection of funds and by 1974, reports of inexplicable wealth of some military governors and public officers were widespread (Nyoni, 2018). The regime was becoming unpopular and was replaced through another coup in July 1975, and General Murtala Mohammed became the military head of state.

General Murtala Mohammed led by example through transparency and declaring his assets and directed all public service officials to do the same. His government also commenced a probe on past leaders. The Federal Assets Investigation Panel of 1975 found ten of the twelve state military governors in the General Gowon's regime guilty of corruption. The guilty persons were dismissed from the military service and made to return ill-gotten properties considered to be in excess of their earnings (Gboyega, in Adegboyega, 2020). The Belgore Commission of Inquiry was initiated to investigate the "Cement Armada". The commission indicted the Yakubu Gowon administration for inflating contracts for cement on behalf of the Ministry of Defence for private gain at a great cost to the government (Umezurike, 2016). The civil service purge witnessed the dismissal of heads of fifty government departments and 11,000 people were retired from the civil service (Onoja, Itodo \& Bebenimibo, 2020). General Mohammed's effort was short-lived as he was assassinated after six months in office.

In 1976, senior public office holders were found guilty of diversion of state resources (Majekodunmi, 2015). Successive governments namely: the administration of President Shehu Shagari (1979-1983); General Ibrahim Babangida (1985-1993); General Sanni Abacha (1993-1998) and General Abdulsalami Abubakar (1998-1999) witnessed cases of corruption (Oni, 2017). After Alhaji Shagari was ousted and replaced with another military government on $31^{\text {st }}$ December, 1983, a tribunal was set up to try offenders and recover stolen resources, and this resulted in at least 51 public office holders being convicted for embezzlement and other forms of abuse of public office (Recommendations of Justice Muhammed Bello Judicial Tribunal of Inquiry to the Review Cases of Persons Convicted Under Decree 3 of 1984, 1986). An audit inquiry in 1994 found General Babangida's administration guilty of diverting $\$ 12$ Billion of excess oil revenue which was accumulated during the First Gulf War (Agbese in Enweremadu \& Ifejika, 2017:).

During President Shagari's administration (1979-1983), it was alleged that over $\$ 16$ billion of oil revenue was lost (Ogunmuyiwa \& Bassey, 2020). The Buhari/ldiagbon regime attempted to restore discipline, dignity and integrity in the country. The War Against Indiscipline (WAI) programme was introduced to instil in civil servants a sense of discipline and improve professionalism in the bureaucracy (Waziri-Azi, 2013). To further reduce corruption in Nigeria, the Recovery of Public Property (Special Military Tribunals) 1984 Act was initiated and it gave authority to the head of the Federal Military Government to freeze bank holdings under Decree No.6 of 1984 and investigate the financial affairs of individuals suspected to be involved in illegal deals and inappropriate self-enrichment activities (Owoade , 1989). This law was considered too severe as suspects were declared guilty before investigations and the predetermined conviction was not less than twenty-one years imprisonment, and where graft cases were more than a million naira, the conviction was either twenty-five years or life imprisonment (Graf as cited in Akinwumi \& Mohammed, 2017).

The Buhari regime was described as draconian as the respect for human rights was abbreviated in its attempt to instil discipline and sanity in public life. The regime was overthrown by General Ibrahim Babangida in bloodless palace coup on $27^{\text {th }}$ August, 1985. Corruption was reported to have reached a new height and had been institutionalised during the Babangida regime, ljewereme \& Dunmade (2014) note that the Okigbo panel was set up under General Abacha to investigate how the General Babangida administration spent extra oil earnings ( $\$ 12.4$ billion) from the Gulf war and also recommend among other things how to reform the Central Bank of Nigeria (CBN) in the light of mismanagement of funds. The full report was never released but the summary alleged that the money was wasted on unproductive ventures and opened the "floodgate" for diversion of public funds (Aluko, 2004).

\subsection{Anti-Graft Initiatives in Nigeria's Democratic Dispensation (1999-2021)}

One major focus of President Obasanjo's administration was to bring an end to corruption in Nigeria and this offered reform-minded Nigerians an opportunity to elect a leader they could persuade to constitute effective anti-corruption measures (Ojukwu \& Chukwuma, 2018). To this effect, the Independent Corrupt Practices and Other Related Offences Commission (ICPC) and Economic and Financial Crimes Commission (EFCC) were established. Other anti-graft institutions are the Nigerian Extractive Industries Transparency Initiative (NEITI), the Due Process Unit, and the Public Procurement Act.

\section{Independent Corrupt Practices and Other Related Offences Commission (ICPC)}

For the first time in Nigeria's history, the Corrupt Practices Act of 2000 established a statutory body 
answerable to the National Assembly and whose aim was solely to fight corruption (Adeyemi \& Adeoye, 2019). The Act vested in the ICPC substantial power to arrest, investigate and prosecute suspects. Section 6 of the ICPC Act of 2000 empowers the commission to:

- Receive and investigate complaints from members of the public on allegations of corrupt practices and inappropriate cases, prosecute the offenders;

- Examine the practices, systems and procedures of public bodies and where such systems aid corruption, direct and supervise their review;

- Advise heads of public bodies of changes in practice, systems, procedures compatible with the effective discharge of the duties of public bodies to reduce the likelihood or incidence of bribery, corruption and related offences;

- Educate the public on and against bribery, corruption and related offences; and

- Enlist and foster public support in combatting corruption.

\section{Economic and Financial Crime Commission (EFCC)}

The EFCC was established as a law enforcement agency that investigates financial crimes such as money laundering and advance fee fraud as stipulated in the EFCC Establishment Act of 2004. The Commission is vested with powers to investigate, prevent and prosecute offenders that engage in money laundering, embezzlement and bribery (EFCC Act, 2004).

\section{The Nigerian Extractive Industries Transparency Initiative (NEITI)}

The NEITI is empowered by the law to promote transparency and accountability in Nigerian oil and gas, and mining resources management. Its major objectives are to ensure that revenues accruing to the federal government from payments made by extractive companies are managed transparently and the money acquired is used to promote development (Izekor \& Okaro, 2018).

\section{The Due Process Unit}

The Due Process also known as the Budget Monitoring and Price Intelligence Unit (BMPIU) is charged with the responsibility of enforcing ethical standards in government activities, thereby ensuring transparency in public procurement and the implementation of projects and programmes (Gberevbie, 2013). Its major goals were to ensure strict compliance of established rules and procedures guiding the process of contract invitation, contract award and project implementation in Nigeria.

\section{The Public Procurement Act}

The Public Procurement Act 2007 serves as a guide to the implementation of any public procurement in Nigeria, this is to ensure value for money, transparency, accountability, efficiency, effectiveness and fairness (Enofe, Okuonghae, \& Onobun, 2015).

\section{CONCLUSION AND RECOMMENDATIONS}

The paper examined the effectiveness of the rule of law as a tool for implementing the anti-graft war in Nigeria. It was deduced that disregard for the rule of law circumscribes the effectiveness of anti-graft agencies and other institutions in the fight against corruption. It was established that corruption is an impediment to the progress of any country, reduces public confidence in government institutions and the values they uphold. The paper highlighted various efforts through several policies, institutions and legislations of government to bring an end to corruption in Nigeria, but identified poor enlightenment/education on this malady. The utilisation of elite theory as the framework of analyses illuminated the discussion which pointed to limited impact of the rule of law on Nigeria's anti-graft war, complicity of the governing and bureaucratic elite and weak institutions of governance.

A major recommendation of this paper is that concerted efforts must be made to build strong institutions of governance and bureaucracy as bulwark against rapacious tendencies and all forms of kleptomania. As a corollary, institutions saddled with upholding moral rectitude, education and enlightenment must mount vigorous crusade against the malaise of corruption, and their autonomy must be guaranteed through adequate funding from first-line charge on the Consolidated Revenue Fund of the federation. 


\section{REFERENCE LIST}

Adegbami, A. \& Uche, C. I. (2016). Despotic Democrats versus Good Governance: Challenges of Administration in Nigeria's Fourth Republic. The Journal of Developing Areas 50(4), 195-210.

Adegboyega, O. O. (2020). Public Morality as a Fulcrum for Social Cohesion and Development in Nigeria: A Philosophical Approach. KIU Journal of Humanities 5(1), 37-48.

Adeyemi, O. O. \& Adeoye, J. O. (2019). Historical Dynamics of the Anti-Corruption War in Nigeria. Public Policy and Administration Research 9(9), 59-64.

Agbese, P. (2005). The 'Stolen' Okigbo Panel Report: Of Malfeasance and Public Accountability in Nigerian Economies. In D. LaRay, \& I. E. Guyer. The Legacy of Pius Okigbo (pp. 55-75). Ibadan: Ibadan University Press.

Akinwumi, O. \& Mohammed, N. (2017). Globalization and Africa's Transition to Constitutional Rule: SocioPolitical Developments in Nigeria. New York: Springer.

Alatas, S. H. (2015). The Problem of Corruption. New York: The Other Press.

Aloko, S. \& Abdullahi, U. (2018). Corruption and Underdevelopment in Nigeria: Challenges and Solutions. Scientific Research Journal 6(7), 1-10.

Aluko, M. (2004, April 25). Why Government Should Release the Okigbo and Oputa Reports- A Question of Credibility. Retrieved from Dawodu.Com: https://dawodu.com/aluko88.htm

Amali, M. O. (2017, March 1). Curbing Money Laundering: Global Reception and Implementation of International Anti-money Laundering Standards: A Case Study on Nigeria. Doctoral Dissertation. Huddersfiled, United Kingdom: University of Huddersfield.

Ayatse, F. H., Onaga, U. B., \& Ogoh, A. O. (2013). Democracy, Good Governance and Development: Nigeria's Experience. IOSR Journal of Humanities and Social Science 8(5), 61-67.

Carino, L. (1979). The Definition of Graft and Corruption and Conflicts of Ethics and Law. Philippine Journal of Public Administration XXIII (3), 221-240.

Code of Conduct Bureau (2021). The Code of Conduct Bureau: History. Retrieved from The Presidency, Code of Conduct Bureau: http://ccb.gov.ng/about-us/history/

Darden, K. (2000). Graft and Governance: Corruption as an Informal Mechanism of State Control. Informal Instituitions and Politics in the Developing World 5(6) (pp. 1-41). Cambridge: Weatherhead Centre for International Affairs, Harvard University.

Dicey, A. V. (2013). The Law of the Constitution (Vol.1). Oxford: Oxford University Press.

Economic and Financial Crimes Commission (2004). Functions of the Commission. EFFC Establishment Act 2004.

Ekundayo, W. J. (2017). Political Elite Theory and Political Elite Recruitment in Nigeria. Public Policy and Administration Research 7(5), 1-8.

Enofe, A. O., Okuonghae, O., \& Onobun, S. I. (2015). The Impact of Public Procurement Act on Government Accountability in Nigeria. Journal of Political Science and Leadership Research 1(8), 114-128.

Enweremadu, D. U. \& Ifejika, S. I. (2017). Institutionalizing Transparency and Accountability in Nigerian Public Procurement Process. Ibadan Journal of Sociology 5(1), 73-107.

Gberevbie, D. E. (2013). Ethical Issues in Nigeria's Quest for Development. Rwanda Journal, Series B: Social Sciences 1(1), 21-35.

Gboyega, A. (1996). Corruption and Democratization in Nigeria. Ibadan: Agba Areo Publishers.

Graf, W. D. (1988). The Nlgerian New Year's Coup of December 31, 1985: A Class Analysis. Journal of Black Studies 16(1), 21-45.

Haruna, B. A., \& Yusuf, A. M. (2017). A Conceptual Analysis of the Rule of Law in Nigeria. Bayero Journal of International Law and Jurisprudence, 101-127.

Heidenheimer, A. J. (1970). Political Corruption. In A. J. Heidenheimer, \& M. Johnston, Comparative Analysis (pp. 4-6). New York: Rinehart \& Winston. 
Ibietan, J. (2013). Corruption and Public Accountability in the Nigerian Public Sector: Interrogating the Omission. European Journal of Business and Management 5(15), 41-48.

Ibietan, J. I., \& Ajayi, O. O. (2015). The Governing Elite and Democratic Consolidation in Nigeria: An Appraisal of the Fourth Republic. Journal of Human and Social Science Research 6(1), 14-21.

ljewereme, O. B. (2015). Anatomy of Corruption in the Nigerian Public Sector: Theoretical Perspectives and Some Empirical Explanations. Sage Journals 5(2), 1-16.

ljewereme, O. B. \& Dunmade, E. O. (2014). Leadership Crisis and Corruption in Nigerian Public Sector. International Journal of Public Administration and Management Research 2(3), 24-38.

Ikejiani-Clark, M. (2001). Corruption in Local Government Administration: Challenges and Remedies. In J. C Ozioko, \& J. I. Onuoha, Contemporary Issues in Social Sciences (pp. 122-137). Calabar/Benin: Baaj International Company.

Iwuoha, C. A. (2019). Religion and the Rule of Law in Nigeria. Tansian University Journal of Arts, Management and Social Sciences, 25-35.

Izekor, A. O. \& Okaro, C. S. (2018). Effect of Corruption on Crude Oil Revenue Earnings in Nigeria (19962015). International Journal of Innovative Research and Advanced Studies 5(1), 9-15.

Lasswell, H. (1936). Politics: who gets what, when and how? Cleveland: Meridian Books.

Majekodunmi, A. (2015). Federalism in Nigeria: The past, current peril and future hopes. Journal of Policy and Development Studies 289 (1850), 1-14.

Nwogu, M. I. (2010). The Rule of Law in Governance in Nigeria. African Journals Online, 1-15.

Nyoni, T. (2018, June 29). The War Against Corruption in Nigeria: Devouring or Sharing the National Cake? Retrieved from Munich Personal RePec Archive: https://mpra.ub.unimuenchen.de/87615/1/MPRA_paper_87615.pdf

Ogunmuyiwa, H. O. \& Bassey, A. E. (2020). Corruption in A Diachronic Corpus of Nigerian Presidential Speeches. Southern African Linguistics and Applied Language Studies 38(2), 95-108.

Ojukwu, E. C. \& Chukwuma, N. C. (2018). The Nigerian State and the Dialectics of Anti-Corruption Crusade in Nigeria (1999-2017). International Journal of Research and Innovation in Social Science II (XII), 124-132.

Onah, R. C. \& Ibietan, O. I. (2010). Fiscal Federalism and Resource Control Option For Nigeria. In R. C. Onah, \& C. N. Oguonu, Readings in Public Administration (pp. 263-286). Nsukka : University of Nigeria Press Ltd.

Oni, E. (2017). Governance and Prebendalism in Nigeria: The past, the present and the future. International Journal of Social Science and Humanities Research 5(4), 424-436.

Onoja, I. B., Itodo, U. F., \& Bebenimibo, P. (2020, April 16). Nigerian Military Narratives and Performance on Corruption Control (1966-1999). Retrieved from Powered by SSRN: https://papers.ssrn.com/sol3/papers.cfm?abstract_id=3571920

Onwanibe, R. C. (1989). The Rule of Law and the Rule of Man. In O. C. Eze, Society and the Rule of Law (pp. 171-189). Owerri: Totan Publishers.

Onyegbula, S. C. (2017, November). The Efficacy of the Nigerian Human Rights Violation Investigation Commission (Oputa Commission) in the Process of Transitional Justice. Retrieved from University of South Africa Repository: uir.unisa.ac.za

Owoade , A. M. (1989). The Military and Criminal Law in Nigeria. Journal of African Law 33(2), 135-148.

Pokharel, T. L. (2019). Power Approaches to Policy-Making. Nepal Commerce Campus 4(1), 171-178.

Rotimi, E. Obasaju, B., Lawal, A., \& Iseolorunkanmi, J. (2013). Analysis of Corruption \& Economic Growth in Nigeria. African Journal of Social Sciences 4(4), 1-19.

Summary of decisions of the Federal Military Government on the recommendations of Justice Muhammed Bello Judicial Tribunal of Inquiry to the Review Cases of Persons Convicted under Decree 3 of 1984 (Federal Republic of Nigeria 1986). 
Transparency International (1999). Transparency International. Retrieved from Corrupt Perceptions Index: https://www.transparency.org/en/cpi/1999

Transparency International (2020). Corruption Perceptions Index 2020. Retrieved from Transparency International: https://images.transparencycdn.org/images/CPI2020 Report EN 0802-WEB-1 202102-08-103053.pdf

Umezurike, G. (2016). Corruption and Leadership in Nigeria: Challenges and Prospects. IDOSR Journal of Current Issues in Arts and Humanities 2(1), 113-120.

Waziri-Azi, F. (2013). Evolution of Anti-Corruption Agencies and Laws in Nigeria. United Kingdom: Lambert Academic Publishing.

Yunusa, A., \& Abuh, P. A. (2016). Corruption and Accountability in the Nigerian Public Sector: An Empirical Discourse. International Journal of Public Administration and Management Research 3(3), 47-54. 